other. It will be inter-disciplinary in approach and will cover all colonial powers in Africa south of the Sahara.

It is intended to produce five volumes over the next ten years dealing with administrators, the military and police, businessmen, planters, mine-owners, technicians, missionaries, teachers, writers, etc., and the relationships of all these with African societies and individuals.

\title{
Captain R. S. Rattray
}

N.P.F. Machin is engaged, with the co-operation of his family, on a biography of the late Captain R. S. Rattray, author of Ashanti, Religion and Art in Ashanti, etc. He would be grateful if any people who knew Captain Rattray and who feel they may have something to contribute to such a biographical study, would get in touch with him. He is particularly interested in contacting anyone who knew Captain Rattray while he was working on the Gold Coast. Mr. Machin's address is: Poplar Farmhouse, Marshside, Canterbury, Kent.

\section{The 'Rediscovered' Material of Laman's Kongo Ethnography}

IN Africa (vol. xlii, no. 4, I 972, pp. 316-28) John M. Janzen writes about the 'rediscovered' material on which Karl Laman based his The Kongo, i-iv (Uppsala, 1955-68), and criticizes 'an obfuscating editorial policy' used in the publishing of this ethnography. The 'rediscovered' material was handed over to Janzen by the archivist Ragnar Widman at the archives of Svenska Missionsförbundet. Widman had devoted a great deal of work to arranging a large number of 'cahiers' written in the Kikongo language by, among others, Laman's Congolese students. There were also manuscripts in Swedish.

Laman wrote an account of the ethnography in Swedish with the intention of publishing it. After his death the editor of Studia Ethnographica Upsaliensia, Professor Sture Lagercrantz, obtained Laman's manuscript and eventually published it in English. His editorial work was based on Laman's own manuscript. The material 'rediscovered' by Janzen was not available to Lagercrantz. These facts were explained to Mr. Janzen by Mr. Widman and myself.

Janzen's article is, however, a contribution towards understanding the base material of Karl Laman's ethnography, but it must also be said that there is much more material to be 'rediscovered' of the work of Laman as a missionary, linguist, and ethnographer.

(Communicated by Dr. Bertil Söderberg and Mr. Ragnar Widman)

'Cultures et développement' (Université Catholique de Louvain) vol. v, no. 2 Articles

Kenneth J. Ackerman. Ways of Being Poor. A Critical Look at the Contribution of Oscar Lewis to an Understanding of the Causes and Consequences of Poverty.

Claude Rivière, Genèse d'inégalités dan l'organisation sociale malinké.

Toyomasa Fuse. Japan's Socio-Economic Development. A Historical Review and Implications for the Third World.

Mahmoud Abdel-Fadil. Note sur les différents modes de développement dans les conditions du socialisme.

Melange

Béatrice de Sincay. Religion et développement.

Chronique Bibliographique

Franz Lejuge. La révolution vietnamienne.

Comptes Rendus 